\title{
"EM NENHUMA OUTRA CIDADE O NÚMERO DE PESSOAS CASADAS É TÃO PEQUENO": CONCUBINATO E CASAMENTO EM GOIÁS (1800-1850)
}

\author{
“NO OTHER CIT HAS SUCH A SMALL NUMBER OF MARRIED PEOPLE": \\ CONCUBINAGE AND MARRIAGE IN GOIÁS (1800-1850)
}

Maria Lemke*

\begin{abstract}
RESUMO
A documentação cartorária e eclesiástica produzida entre 1800 e 1850, relativa a Vila Boa, capital da capitania de Goiás, sugere que os viajantes estavam certos ao apontarem para a frequência e naturalidade com que o concubinato acontecia. No entanto, concubinato não pode ser confundido com ausência de valores familiares, pois tais valores, assim como bierarquia e disciplina católica, eram os pilares das sociedades do Antigo Regime. A partir de uma perspectiva relacional, o objetivo deste artigo volta-se à investigação das famílias e ao papel da disciplina católica na compreensão de como aquela sociedade marcada pelo concubinato se organizava a partir de relacōos familiares e de como a bierarquia as naturalizava.
\end{abstract}

PALAVRAS-CHAVE: Casamento. Concubinato. Igreja Católica. Antigo Regime.

\begin{abstract}
The ecclesiastical and notary's office records from 1800 to 1850, regarding Vila Boa, capital of the captaincy of Goiás, suggest travelers were right to point out the frequency and naturality of concubinage in the city. However, concubinage can't be mistaken for a lack of family values, because such values, as well as hierarchy and catholic discipline, were the pillars of the Old Regime societies. From a relational perspective, this article aims to investigate the families and the catholic discipline role in understanding how a society marked by concubinage organized itself based on family relationships and how hierarchy normalized them.
\end{abstract}

PALAVRAS-CHAVE: Marriage. Concubinage. Catholic Church. Old Regime.

Ao descreverem suas passagens por Goiás, os viajantes foram unânimes em relatar a raridade dos casamentos. Tão raras seriam as uniões abençoadas pela Igreja que os nubentes amiúde seriam motivo de escárnio. Para Saint-Hilaire, à ausência de casamentos somar-se-ia a libertinagem. O francês creditava tais costumes aos primeiros aventureiros que, embora se unissem a negras e índias carnalmente, não se casavam por orgulho. Ele supunha que essa situação também teria sido comum em Minas Gerais,

\footnotetext{
* Professora da Universidade Federal de Goiás (UFG). Doutorado em História pela Universidade Federal de Goiás (UFG). Email: marialemke@gmail.com
} 
mas, em face da proximidade com o Rio de Janeiro, a província vizinha teria recebido maior número de mulheres de "bons costumes":

Em nenhuma outra cidade o número de pessoas casadas é tão pequeno (1819). Todos os homens, até o mais humilde, têm uma amante, que eles mantêm em sua própria casa. As crianças nascidas dessas uniões ilegítimas vivem ao seu redor, e essa situação irregular causa tão pouco embaraço a eles quanto se estivessem casados legalmente. Se por acaso algum deles chega a se casar, passa a ser motivo de zombarias [...] a libertinagem tornou-se um hábito [...] e o povo vê-se constantemente estimulado a entregar-se a ela pelo mau exemplo dos que o governam (SAINT-HILAIRE, 1975, p. 53).

Johann Emanuel Pohl usou palavras igualmente ácidas. Para este viajante, o concubinato seria manifestação de desregramento moral, pura lascívia: "Neste país a moralidade é extremamente baixa [...]. Os sagrados laços do matrimônio são aqui muito frouxos e pouco apreciados. Quando aqui se realiza um casamento, habitualmente é o ouro o catalisador da união"(POHL, 1976, p. 142). O casamento, conforme suas palavras, seria uma união alicerçada no interesse econômico.

Os excertos acima indicam quão comum era o concubinato e a naturalidade com que ocorria. Segundo os viajantes, sequer os padres escapariam dos pecados da carne. Estes, além de batizarem os rebentos dos governadores sem o menor constrangimento, viveriam concubinados com suas amásias, mantendo seus filhos sacrílegos sob o mesmo teto. Governadores também manteriam proles ilegítimas e concubinas no palácio.

A documentação cartorária e eclesiástica produzida entre 1800 e 1850, relativa a Vila Boa, sugere que os viajantes estavam certos ao apontarem para a frequência e naturalidade com que o concubinato acontecia naquela sociedade. No entanto, concubinato não pode ser confundido com ausência de valores familiares, pois tais valores, assim como hierarquia e disciplina católica, eram os pilares das sociedades de Antigo Regime. ${ }^{1}$ A partir de uma perspectiva relacional, o objetivo deste artigo volta-se à investigação das famílias e ao papel da disciplina católica na compreensão de como, aquela sociedade marcada pelo concubinato, se organizava a partir de relações familiares e como a hierarquia as naturalizava. ${ }^{2}$

Apesar das diferenças, casamento e concubinato eram relações familiares que contribuíam tanto para a promoção social como para a manutenção de hierarquias. Antes de prosseguir, uma primeira distinção deve ser feia, entre casamento e concubinato. Conforme Silvia Brügger (2007), o casamento voltava-se mormente aos interesses políticos e econômicos, enquanto o concubinato, à satisfação de interesses pessoais. Visto dessa forma, concubinato e casamento sacramentado não eram antagônicos, mas relações que atendiam a "funções distintas". Nesse sentido, a se pensar num inventário das diferenças, o casamento ocorria entre iguais, ou entre pessoas de "qualidades próximas" - acontecia no

\footnotetext{
${ }^{1}$ Sobre disciplina católica, ver Fragoso (2015, 2018) e Hespanha (2010, 2011). Sobre Antigo Regime nos Trópicos, ver Fragoso $(2001,2015)$.

2 Sobre hierarquias sociais amparo-me nas proposições de Fragoso (2011, 2014, 2016) e Guedes (2014).
} 
plano horizontal. Já o concubinato, manifestava sentimentos e interesses pessoais, era a união entre pessoas de diferentes qualidades e ocorria, portanto, no plano vertical (2007). ${ }^{3}$

Nas palavras de Sheila Faria (1998, p. 134), "Casamentos e recasamentos legais orientavam a estabilidade. Dificilmente um homem ou mulher sozinha poderia sobreviver na zona rural. Buscar a estabilidade do matrimônio era a solução priorizada." O casamento sacramentado era estratégia de criação e fortalecimento de alianças e status, mas também de segurança material, na manutenção de bens. Se as fortunas eram voláteis no período colonial, o casamento garantia os bens na família, evitando sua dispersão, conforme Faria (1998).

Se retomarmos à citação com a qual abri este artigo, veremos que Saint-Hilaire - a seu modo forneceu pistas de que, à época, sabia-se bem a diferença. Por outro lado, se, de fato, podemos afirmar que o concubinato era frequente e naturalizado, isso não autoriza a assertiva de que casar-se in facie ecclesiae era motivo de mofa. Pelo contrário, casar-se proporcionava status, distinção. Casamento sacramentado fazia parte da lógica das sociedades de Antigo Regime e daquelas com traços de Antigo Regime, o caso da América lusa. Silvia Brügger atentou para o fato de que as regiões de mineração não estavam isentas de famílias, tampouco da vida política ou de jogos de interesses. Dito de outra forma, as relações sociais tinham como referencial os laços familiares, consanguíneos ou não (2007). É sob a perspectiva de análise proposta pela autora que analiso as famílias: não apenas os laços consanguíneos, tampouco a quantidade de filhos ou pessoas morando sob o mesmo teto, mas, como pertencimento e, sobretudo, como sustentáculo daquela sociedade.

Vale ressaltar que a noção de família naquela época distinguia-se da dos nossos dias. Sheila Faria (1998) destaca que "o sentimento de pertencer a uma família específica transcendia a consanguinidade e se manifestava entre os parentes rituais." Ainda conforme a autora, naquela sociedade, genros eram tratados como filhos, sogras como mães, aos afilhados eram deixadas doações, indicando preocupação com seu bem-estar. Mediante tal conformação, com a relação de pertencimento sendo engendrada a partir do parentesco ritual, como aquele gerado pelo batismo, um indivíduo poderia descartar um apelido (sobrenome) ao longo da vida e adotar outro, como parte de suas escolhas e estratégias de reconhecimento social e pertencimento (HAMEISTER, 2006).

Além de várias familias se assentarem em Goiás desde as primeiras décadas de achamento do ouro e não ter sido o ouro a prendê-las ${ }^{4}$, a existência de uniões não legitimadas não impediu a formação de compadrios e amizades. Nesse sentido, o concubinato é uma relação que não pode ser confundida com ausência de valores familiares. Definitivamente, não estamos diante de uma sociedade bastarda, na qual as crianças eram abandonadas ao deus-dará ou ficavam sem o batismo. Pelo contrário.

A compreensão de família, além de pertencimento, perpassa hierarquia. À época, não se discutia se as filhas gostariam de casar-se com fulano ou sicrano. A hierarquia, fundamentada em preceitos

\footnotetext{
3 Interpretação semelhante está em Sheila Faria (1998, p. 140-143).

${ }_{4}^{4}$ Para Moraes (2012), o ouro foi responsável pela descoberta de Goiás; a religiosidade, por fixar a população.
} 
católicos, implicava na obediência amorosa. ${ }^{5}$ Aquela era uma sociedade cuja disciplina cristã- leia-se católica ${ }^{6}$ - abarcava a todos, indistintamente. Naquele mundo de hierarquias, a família era um dos pilares.

Freyre (1983, p. 443) já afirmava que havia sido a família a instituição modeladora. Não havia política sem laços familiares, tampouco honra sem pertencimento. Com efeito, o concubinato era comum. No entanto, isso não inviabilizava o reconhecimento e a incorporação de filhos de fora do casamento no seio da família. Em sentido paralelo, numa sociedade marcada pela disciplina católica, o casamento hierarquizava.

A disciplina católica determinava o reconhecimento de filhos tidos fora do casamento. Aliás, o sentido hierárquico que o casamento assumia impediu o ex-governador de Goiás (1808-1811), Fernando Delgado Castilho, de levar sua concubina para Lisboa. Ao embarcar no porto do Rio de Janeiro, sua amásia teria dito a Castilho que o acompanharia somente na condição de legítima esposa. Segundo SaintHilaire (1975, p. 56), “[esses] sofrimentos - segundo dizem - lhe tiraram a lucidez de raciocínio, não pôde suportar o dilema no qual se encontrava." É de Pohl a informação de que o ex-governador teria escrito uma carta recomendando os dois filhos "à clemência do rei, acrescentando que morreria como homem honrado, do que era prova sua pobreza": seus filhos deveriam ser levados ao Reino e lá receber educação (POHL, 1976, p. 137-138). Diferente de Saint-Hilaire, Pohl afirmou que Castilho cometeu suicídio por ter sua solicitação de patente de Conselheiro Real em Lisboa negada. Malgrado não ter se casado com a filha de um carpinteiro, Castilho reconheceu os filhos, pedindo que a graça real os amparasse. Tomando por base a diferenciação entre concubinato e casamento elaborada por Brügger, torna-se mais fácil compreender o dilema do ex-governador. Casar-se era da ordem do status, ocorria entre iguais. A filha do carpinteiro e o governador não eram iguais. Embora nesta América os valores fossem mais fluidos em relação ao reino, uma coisa era viver concubinado, outra, bem diferente, era casar-se com uma mulher de família sem nome ou estirpe.

O célebre caso do governador amasiado com a filha de um carpinteiro ocorreu dez anos antes de Saint-Hilaire visitar Goiás. No entanto, além de ter ficado na memória, não foi o único. Francisco de Assis Mascarenhas - conde da Palma, posteriormente marquês de São João da Palma, e primeiro ministro da Casa de Suplicação no Brasil - governou Goiás entre 1804 e 1808. Como seu sucessor, também deixou dois filhos naturais em Vila Boa, tidos com dona Ângela Ludovica de Almeida. ${ }^{7}$ O exemplo do que ocorreu com o concubinato de Francisco de Assis Mascarenhas e Ângela Ludovico indica quão aceitável o concubinato se tornava naquela sociedade. Ângela, depois do concubinato com o governador, contraiu núpcias com o primo José Rodrigues Jardim. ${ }^{8}$ Levando em consideração que eram famílias com alguma projeção local, é provável que Ângela "tenha sido casada" com o primo tenente, pois estava sujeita aos arranjos políticos de sua família para garantir status. Quiçá, cause maior estranheza que o fato de a primeira filha do casal chamar-se Francisca e que tenha sido apadrinhada pelo governador Francisco

\footnotetext{
${ }^{5}$ Ver Hespanha (2010, 2011).

${ }^{6}$ Sobre disciplina católica, ver Fragoso (2015) e Hespanha (2010, 2011).

${ }^{7}$ O romance Chegou o Governador foi inspirado na relação entre Ângela e o governador. Cf. Élis (1998).

8 Sobre José Rodrigues e Ângela Ludovica, ver Freitas (2009).
} 
de Assis Mascarenhas, antigo amásio de Ângela. Esse certamente foi o arranjo político de maior envergadura que o casamento de Ângela e José Rodrigues representa. ${ }^{9}$ José Rodrigues foi tesoureiro da Casa de Fundição durante o governo de Francisco de Assis Mascarenhas. Além de ter se casado com Ângela, tornou-se compadre do governador, tinha cargo de confiança. Casar, era, de fato, um elemento de distinção social. A estreiteza com que as relações ocorriam deixaram o viajante desnorteado.

Os casos que ocorriam no palácio não foram os únicos. Também Ângela não foi a única a se casar após ter tido filhos no estado de solteira. Ou seja, o concubinato não era óbice ao casamento. Dona Maria Angélica de Artiaga, ao batizar Maria, em 1806, registrou que a criança era filha de pai incógnito. Dificilmente saberemos quem foi o pai. Porém, Maria Angélica não viveu sozinha, nem solteira, pelo resto da vida. Os outros quatro filhos, Pulchério, Antônio, Francisco e Rita, batizados respectivamente em 1813, 1815, 1817 e 1820, foram frutos de união legitimada pela Igreja com o capitão José Joaquim Pulchério dos Santos. Todos os filhos de dona Maria Angélica foram apadrinhados por homens com patentes e mulheres com a qualidade de dona. ${ }^{10}$

De acordo com as Constituições Primeiras do Arcebispado da Bahia, o vínculo do matrimônio, uma vez consumado por cópula carnal, tornava-se indissolúvel. Acabava somente com a morte de um dos cônjuges..$^{11}$ Nisso reside a diferença entre o matrimônio e a união concubinal: o primeiro era um estado; o segundo, situação que poderia - aos olhos da Igreja deveria - ser (e era) alterada ao longo da vida e Ângela e Maria Angélica são exemplos disso.

Retomando Saint-Hilaire, suas observações são próximas das de outros viajantes e militares que passaram por Goiás. ${ }^{12}$ Essa unanimidade quanto às observações e "explicações" se deve ao contato que tiveram. Silva e Souza cedeu seu manuscrito das "Memórias", escritas em 1812, a Saint-Hilaire. Por sua vez, o padre fundamentou parte de seus escritos de 1832 nas conversas com Pohl. Quando publicou sua Viagem, em 1848, Saint-Hilaire referiu-se mais de uma vez aos relatos de Pohl, Silva e Souza, Gardner e outros. Por isso, parte do que escreveram são complementações e convergências. Nesse sentido, a interlocução entre esses viajantes e suas obras deu-lhes foro de verdade, amalgamando as imagens lidas e (re)produzidas pela historiografia (RIBEIRO, 2004, p. 2).

Saint-Hilaire observou que o concubinato ocorria até entre os padres. Afirma o francês:

Os próprios padres, cuja vida deveria constituir um permanente protesto contra desregramentos que contrariam não só as leis da religião e da moral, mas também o progresso da civilização e a instituição da família e da sociedade, autorizam por seu mau comportamento a devassidão dos fieis que lhe são confiados. Suas amantes moram com eles, seus filhos são criados ao seu redor, e muitas vezes - digo-o com relutância - o padre faz-se acompanhar da amante quando vai à igreja (SAINTHILAIRE, 1975, p. 53).

\footnotetext{
${ }^{9}$ Sobre os filhos de Francisco de Assis Mascarenhas, ver Bittar (1997).

10 Arquivo Geral da Diocese de Goiás, doravante AGDG. Livro de batismo, Goiás 1763-1813, f. 27; Livro de batismos 18131842 , f. $1,34 \mathrm{v}, 59 \mathrm{v}, 125$, respectivamente.

11 VIDE, D. Sebastião M (1853, Tit. LXXII, p. 126).

${ }^{12}$ Seria enfadonho reproduzir Ayres de Casal, Burchel. D’Alincourt e outros. Sobre os viajantes em Goiás, ver Ribeiro (2004), Chaul (1997), Corrêa (2001).
} 
Quem sabe, Saint-Hilaire tenha se referido ao padre Luís Antônio da Silva e Souza, a quem conheceu e de quem leu as "Memórias". O padre Silva e Souza fez seu testamento em abril de 1820 e deixa entrever como a moral cristã era presente no cotidiano. A assunção da culpa diante de Deus e o testamento do padre são bons exemplos de mea culpa e de como se recorria à corte divina:

Em nome da Santíssima e Individua Trindade Padre, Filho, e Espírito Santo, Três pessoas distintas e um só Deus Verdadeiro, em quem firmemente creio em cuja fé vivo [...] estando eu em meu perfeito juízo e em estado de saúde e conhecendo por Misericórdia de Deus que o tempo da minha resolução não pode tardar, depois de cinquenta e seis anos de idade e que devo ser chamado talvez logo a dar contas dos talentos confiados à administração de um Servo tão indolente como tenho sido, vendo-me com as mãos vazias de boas obras por perder tanto tempo de minha vida à procura de agradar mais aos homens do que de ordinário de nada se satisfazem que a um Deus Bemfeitor, que além de me remir no Cativeiro do pecado tem marcado todos os instantes de minha existência com imensuráveis benefícios; arrependido de todas estas faltas, recomendo a Graça do Onipotente, que gratuitamente se oferece a todos para a reparar quanto é tempo, pretendo de hoje em diante regular como Católico Romano [...] Deposito, antes de tudo, a minha alma no seio da Misericórdia Divina, e confio no preço infinito do Sangue Preciosíssimo [...] Suplico a meu benefício a proteção da Mãe Santíssima de Deus, de todos os Santos e Santas da Corte do Céu de meu Pai São Pedro, do Anjo de minha guarda, Santo do meu nome e espero que sejam meus intercessores (apud TELES, 1998, p. 198-1990).

Poderá ser alegado que a constante intercessão aos santos e a toda a corte do céu não passava de uma fórmula pronta. Mas é aí que reside a importância que a salvação da alma assumia nas sociedades com traços de Antigo Regime. ${ }^{13}$ Ademais, incorrer em "fragilidade humana" não significava ausência de fé na vida além-túmulo.

Quiçá, ao visitar o dito padre, Saint-Hilaire tenha se deparado com Maria Luiza, a quem o padre reconheceu, mediante carta régia, como filha. Esta, quando testou, em 1843, declarou que "nunca fui cazada, e nesta Cidade sempre vivi em Companhia do dito meu Pay."14 Não custa um pouco de imaginação para visualizar o padre sendo visitado pelo francês que, por sua vez, observava toda aquela proximidade com assombro e reprovação.

Maria Luiza não foi a única filha de padre em Goiás. Tampouco foi a única a ser reconhecida em testamento. Vários outros padres o fizeram. O padre Martinho Pereira Pedroso, por exemplo, reconheceu quatro filhos, das duas moças celebrou o casamento. Luis Felipe de Carvalho foi ainda mais longe. Teve nove filhos "por fragilidade humana", sendo oito em Vila Boa, com Ludovica Teixeira de Carvalho. Porém, nos livros compulsados somente encontrei três referências a Ludovica, e nestas os três filhos foram registrados como naturais. O outro filho do padre Luis Felipe de Carvalho, Ildefonso, foi

\footnotetext{
${ }^{13}$ Desde a Idade Média, a Igreja se esmerou em difundir a crença na salvação da alma. O medo da morte foi mecanismo para regular comportamentos, difundir a caridade e a solidariedade, preceitos cristãos amplamente difundidos por diversas ordens religiosas. Mas a instituição que induziu ao medo da morte alimentou a esperança da salvação. Não foram poucos os manuais de bem morrer. Para uma história da difusão do medo no Ocidente, ver Delumeau (1989). Sobre o medo da morte, ver Ariès (1989).

${ }^{14}$ Instituto de Pesquisas e Estudos Históricos do Brasil Central, doravante IPEHBC. Livro de registro de testamentos do Juízo Municipal desta Cidade de Goiás. Testamento de Dona Maria Luiza da Silva e Souza, f-12-13.
} 
fruto de relacionamento com Florença “de Tal", no arraial de Couros, no norte da capitania. Por onde quer que tenham passado, os viajantes se depararam, amiúde, com padres e suas concubinas.

Wellington Moreira (2010), ao investigar as paternidades sacrílegas em Goiás, aventou a hipótese de que, no caso do padre Felipe, o fato de ser ele próprio filho natural contribuiu para que "olhasse com naturalidade para o seu relacionamento e para a sua prole." Conforme o autor, o padre Luís Felipe de Carvalho foi um dos poucos a declarar o nome da mãe de seus filhos. Na verdade, foi além: instaurou dona Ludovica como "administradora e tutora dos bens e dos filhos, pois acreditava que "nenhuma outra pessoa será capaz de zellar e conservar os bens dos menores mais do que ella” (MOREIRA, 2010, 179-180).

O padre José Militão Xavier de Barros foi testemunha de abertura do testamento do padre Luis Felipe de Carvalho. Certamente Militão sabia dos filhos e dos relacionamentos do padre Luis Felipe. Militão deve ter se surpreendido mesmo com o testamento do padre Antônio Mariano de Castro, aberto em fevereiro de 1841. No documento, reconhece os oito filhos tidos com sete mulheres, tudo por "fragilidade humana":

Declaro que por fragilidade humana tive os seguintes filhos, Antonio Rafael havido de Dona Francisca das Chagas, mulher solteira, moradora na Cidade de Sam Paulo, Joaquim e José havidos de Antonia Lopes, mulher solteira, Francisco havido de Simplicia Barbosa, mulher solteira, Lourenço havido de Dona Felisberta da Neiva Solteira, Joaquim havido de Anna mulher solteira filha de Anastacia Crioula; Maria havida de Joana Baptista, Maria havida de Constancia ja fallecida, irmaa do soldado José Vicente, os quaes meus filhos instituo meus universaes herdeiros de todos os meus bens, depois de pagas as minhas dividas e cumpridos os meus legados (apud MOREIRA, 2010, 179-180).

Se esses religiosos negaram o celibato, se desrespeitaram as prescrições da Santa Madre Igreja, não deixaram os filhos ao relento. Os vários casos citados demonstram a preocupação com o bem dos filhos. ${ }^{15}$ Saint-Hilaire estava certo ao notar que os padres viam com naturalidade o concubinato e que assumiam seus filhos. Só errou ao tomar tais relações como sinônimo de ausência de valores familiares.

Outro caso merece ser mencionado. Trata-se do padre José Dantas de Amorim, exposto em casa do capitão Domingos José Dantas de Amorim, cuja irmã por parte de pai, era dona Joanna Archangela Xavier. Em seu testamento dona Joanna declara que, à época em que testou, 1844, era casada há dezoito anos com o capitão João Evangelista da Silveira Rosa e com ele não teve filho algum. Porém, declarou:

No estado de solteira tive um filho o qual hé o padre Mestre Jozé Ribeiro Dantas de Amorim, que se criou por enjeitado na casa do falecido capitão [...] Domingos Ribeiro Dantas de Amorim Padrinho e Tio do mesmo meu filho, a quem reconheço, habilito e declaro por meu filho único, que tenho, ao qual instituo por meu legítimo herdeiro da meação de meus bens. ${ }^{16}$

\footnotetext{
15 Alessandra Silveira (2005), em seu estudo sobre o concubinato no bispado do Rio de Janeiro, também verificou que, ao fazerem seus testamentos, os padres procuravam dar encaminhamento econômico aos filhos e às mulheres com quem viveram.

${ }^{16}$ IPHEBC. Livro que há de servir para Registro dos Testamentos do Juízo Municipal desta Cidade de Goiás. 1842, f. 22v.
} 
O reverendo José Dantas de Amorim receberia uma herança nada desprezível. Além de parte da casa onde morava seu marido, dona Joanna deixou ao filho o escravo Cassimiro, pardo, ao qual ela já havia passado carta de liberdade "gratuitamente pelo muito amor que lhe tinha", e pedia ainda ao dito seu filho que "chame para o seu poder o referido Cassimiro, que lhe de huma boa educação, mandandolhe ensinar hum officio, e que ao depois de ser homem lhe entregue sua carta de liberdade."17

Reconhecer filhos na proximidade de "prestar contas a Deus" e para "desencargo de consciência" torna ainda mais difícil aceitar que estamos diante de uma sociedade destituída de valores morais. Ao contrário do que imaginaram os viajantes, a religião não consistia na forma, mas era o que dirigia aquela sociedade. A disciplina católica movia a sociedade.

Márcio Soares (2009), estudando as alforrias em Campos dos Goitacazes, verificou que os senhores de escravos reconheciam seus filhos ilegítimos com escravas. Por questões morais e religiosas, libertavam os rebentos e, na hora de testar, não raro, legavam àqueles parte da herança. Segundo Soares, além da preocupação com a salvação da alma, havia o apelo moral de não deixar nenhum descendente sob o jugo do cativeiro (2009). Ora, se isso ocorria até com a prole tida com cativas, não me parece crível que padres, na possibilidade de penar sem fim no Purgatório, simplesmente esqueciam e negavam seus filhos. O receio pairava sobre o castigo divino e não sobre a condenação terrena (FARIA, 1998; SOARES, 2009).

Assumir os "pecados da carne" tornava-se uma forma mais efetiva de conseguir o perdão do Criador. Aliás, é bom reforçar que os testamentos do período colonial diziam menos da distribuição de bens materiais e muito mais sobre a salvação da alma. Nesse sentido, não era um acerto de contas com a sociedade - embora o pagamento de dívidas e outros penhores constituíssem aqueles documentos. Era a própria salvação da alma que estava em jogo (PAIVA, 2009). Não é de se estranhar que, mais que outros mortais, os religiosos procurassem se livrar da danação eterna. Poderá ser alegado que a constante intercessão aos santos e à corte do céu não passava de uma fórmula pronta. Mas aí reside a compreensão do alcance que a importância a salvação da alma assumia naquela sociedade.

Naquela época, a distinção social não estava assentada em valores capitalistas, por assim dizer, mas no nome familiar, na honra. Fazer parte de uma família influenciava no status e classificação social. Por isso, os filhos naturais, apesar de, em primeiro momento não receberem o mesmo montante e amiúde serem excluídos da herança, acabavam beneficiados com a herança imaterial: a rede de compadrios, solidariedades e o prestígio que o nome da família proporcionava. Legar isso aos filhos era comum. Se era, de fato, uma sociedade na qual o concubinato era corriqueiro, isso não significa que os rebentos dessas uniões não fossem reconhecidos. Insisto: não poderia ser diferente numa sociedade marcadamente católica. Foi isso que fez o capitão Duarte de Mello e Castro reconhecendo sua filha Delfina em 1818.

${ }^{17}$ IPHEBC. Livro que há de servir para Registro dos Testamentos do Juízo Municipal desta Cidade de Goiás. 1842, f. 22. 
Aos dez oito de Setembro de mil oitocentos e dezoito anos, nesta Catedral de Santa Anna de Villa Boa de Goyaz batizei e pus os Santos Óleos a Delfina inocente filha declarada por Duarte de Mello e Castro Tenente coronel e Ajudante de Ordens deste Governo de Goyaz e Donna Escolástica Maria de Camargo solteira foi Padrinho o Coronel Ajudante de Ordens do Governador desta Capitania Álvaro Joze Xavier e para constar faço este assento que assigney // O coadjutor João Pereira Cardozo. ${ }^{18}$

O capitão Duarte de Mello e Castro além de declarar a paternidade, legitimou Delfina. Em seis de março do ano seguinte, mandou passar escritura de legitimação da dita sua filha Delfina Antonia de Mello e Castro "para que como legitimada fosse herdar a sua fazenda e suceder-lhe em toda a sua Herança, Honra e Nobreza." 19 Como se pode observar, Delfina herdou do pai não apenas a fortuna, mas algo primordial para a época: o nome.

Assumir os filhos ilegítimos não ocorria, entretanto, apenas no testamento. Luís Manoel da Silva Caldas tinha negócios nas praças do Rio de Janeiro, Cuiabá e Goiás, além de ser tenente. Numa de suas viagens de negócio à corte, soube que sua mulher fora assassinada por uma escrava em 5 de julho de 1826, na fazenda Sobradinho. Com a morte da mulher, Luís Manoel passou a residir em São João Del Rei e, de lá, enviou carta aos filhos solicitando que fossem morar com ele. Genro e sogra foram incluídos como filho e mãe:

Filhos de minhas entranhas, recebi as vossas ternas letras, e quando me deverão consolar minha aflita alma ellas me abrirão novas feridas pelo anuncio de maior desesperação. Eu me achava no fundo de huma cama prostrado da mais violenta dor pelas noticias dezestradas [sic] de tal forma que athé hoje cada vez mais vou caminhando para o Tumulo. Esses verdugos da humanidade cortaram os fios da mais precioza vida que a minha dependia da conservação de minha amável e querida espoza [...] agora são perdidas todas as minhas esperanças [...] eu na consideração de perder o que mais amava no mundo, e huma companhia de mais de trinta anos [...] em tantas amarguras e afliçoens, e por isso pesso a meus queridos filhos juntos, que pelo amor de Deus, se unam a este desgraçado velho, que desde sua meninice sempre viveu carregado de desgostos e trabalhos [...]. E senhor Ângelo meu caro filh $o$, mandem dizer se lhe foi sua licença para se vir embora com minha filha $[. .$.$] visto que não tenho outras relíquias senão minha família. { }^{20}$

Luis Manoel narra que, ao saber da tragédia, vagou pelos campos, cheio de dores de estômago, até chegar perto de São João del Rei, na esperança de que, em algum lugar, suas moléstias fossem minimizadas. O tenente manifestou toda sua dor ao saber da morte de sua mulher. Contudo, isso não impediu de que tivesse, no tempo de casado, uma filha natural com uma certa Hermínia Senhorinha, no arraial de Paracatu. Trata-se de Tereza Luiza da Silva Caldas. O reconhecimento foi feito em codicilo, em dezembro de 1839. Segundo Pinheiro (2002), Tereza casou-se na cidade de Goiás com o capitão Luiz José da Rocha Maia no oratório particular da casa do tenente Caldas. Para indicar quão complexas eram as relações familiares, vale destacar que não foram os filhos legítimos que acompanharam Luís Manoel para São João Del Rei. A tarefa de segui-lo coube à filha legitimada Tereza e seu marido. A filha natural

18 AGDG. Livro de Assento de batismos. 1813-1842, f. 89.

19 Cartório do Primeiro Ofício da Cidade de Goiás, doravante CPOCG. Livro de Notas, 1823, f. 16-16v, grifos meus.

${ }^{20}$ CPOCG. Livro de notas, n. 49, f. 26-27v. 
foi, portanto, não apenas reconhecida pelo pai, mas incorporada à família quando o marido assumiu a tutela dos sobrinhos.

Também o comerciante Francisco Pereira Caldas incluiu as filhas ilegítimas no seio da família sacramentada. Francisco trouxe para sua companhia - e à de sua mulher - duas filhas naturais. Ofereceuas a Francisco Bueno de Azevedo, afirmando que ambas sabiam "tudo o que uma mulher deve saber para governar uma caza." Mas se isso não bastasse, contou que sua filha legítima, casada com Raimundo Nonato Hyacinto, não deixou herdeiro algum "logo, portanto, são minhas herdeiras as Filhas naturais brancas e de muito boa família do Cuiabá." Francisco Pereira Caldas, quiçá, não se importasse se as filhas se apaixonassem ou não, pois estava "cansado, e precisava de hum companheiro" para ajuda-lo, pois "muito preciso de buma pessoa que trabalhe como próprio, muito principalmente para tomar conta da Caza do Cuyabá donde tenho ainda muito negócio.” Naquela época, não era o amor romântico o catalisador da vida conjugal (BRUGGER, 2007). Por isso, não deve causar estranhamento quando, além de oferecer as filhas, convidou seu xará para sócio e para trabalhar no comércio aludindo à proteção que poderia dar: “Eu sou bom Pay e portanto pode Vossa mercê pois contar com toda a minha proteção.”Em um ano tudo estava arranjado. Era 15 de março de 1832, quando solicitou ao futuro genro que não se demorasse nos "seus arranjos" para que em "fins de maio vá para o Cuiabá tomar conta do que nos pertence." (PINHEIRO, 2010, p. 25)

Alguém poderá questionar por que, apesar de o casamento gerar status social, homens e mulheres caíam em pecado. Primeiro, era da ordem do humano. Por acréscimo, quanto à assunção de filhos ilegítimos e sua incorporação à família, vale destacar que aquela sociedade era regida pela disciplina católica. Segundo Hespanha (2011, p.13), “a ideia de liberdade auto-responsabiliza, transformando a consciência em juiz de si mesma, originando sentimentos dissuasores da transgressão, como má consciência, o remorso, o arrependimento e a vontade firme de emenda." Podia-se até incorrer no pecado da carne, mas o remorso cobrava atitudes.

O eixo de compreensão do mundo sustentava-se numa concepção naturalizada das diferenças, das desigualdades. Com arguta acuidade, Manuel Hespanha (2010, p. 47) asseverava que o "mundo moderno nasceu com a necessidade de ordenar. Deus aparece no meio do caos "dando ordem às coisas". Dias e noites, terra e água, água doce e água salgada... a ordem referendava as diferenças entre as coisas. E tudo era perfeito, dentro das desigualdades criadas naquele momento. Hierarquicamente, em suas diferenças, todas as coisas estavam entrelaçadas e em harmonia. Aliás, a harmonia era uma das virtudes daquele mundo de perfeição que, por sua vez, sugeria obediência e aceitação. Respeitar a ordem natural das coisas era manter-se em seu lugar. Isso se aplicava a todos. Ainda conforme o autor, naquele mundo vigia a graça, a liberalidade, a honra, a honestidade e a verdade. Viver honestamente era aderir à ordem natural (HESPANHA, 2011, 2010). Por isso, tanto Luís Manoel da Silva Caldas, quanto Francisco Pereira Caldas, não excluíram os filhos naturais, mas os incorporaram nos processos de administração dos bens e no seio da família. 
Definitivamente, a noção de família era muito mais ampliada do que a mera contraposição entre casamento e concubinato, frequentemente referenciada nos viajantes. A disciplina católica, amplamente difundida, contribuía para que os erros, quando não corrigidos, fossem minorados. Francisco Pereira Caldas, e tantos outros da época, não sabia conceitos como hierarquia e reciprocidade desigual. Mas os praticou bem. Ao tempo em que arranjava alguém para ajudá-lo a administrar seu negócio, garantia proteção. Quem sabe, seu genro, quando perguntado a que família pertencia, não hesitasse em responder: da casa de Francisco Pereira Caldas. Afinal, a gratidão era um dos princípios que confirmava a hierarquia, o ordenamento político e social (CARDIM, 1999).

Se retomarmos as primeiras citações deste artigo, não será exagero afirmar que Saint-Hilaire tinha alguma razão ao se referir à amplitude com que o concubinato existiu, desde os mais pobres até entre governadores e padres. Contudo, isso não significava ausência de valores familiares, menos ainda abandono de rebentos. O número de pessoas casadas pode até ter sido pequeno, mas, definitivamente, a força e a profundidade com que se teciam as redes familiares se formavam, a distinção que o casamento assumia, a não.

\section{REFERÊNCIAS}

ARIÈS, P. Sobre a história da morte no Ocidente: desde a Idade Média aos nossos dias. Lisboa: Teorema, 1989.

BITTAR, M. J. G. As três faces de Eva na Cidade de Goiás. Dissertação (Mestrado em História) Universidade Federal de Goiás, Goiânia, 1997.

BRÜGGER, S. M. J. Minas patriarcal. Família e sociedade (São João del Rei-séculos XVIII e XIX). São Paulo: Annablume, 2007.

CARDIM, P. Amor e amizade na cultura política dos séculos XVI e XVII. Lusitania Sacra, 2 a série, v. 11, p. 21-57, 1999.

CHAUL, N. F. Caminhos de Goiás: da construção da decadência aos limites da modernidade. Goiânia: Cegraf;UFG, 1997.

CORRÊEA, M. M. S. Naturalistas e viajantes estrangeiros em Goiás (1800-1850). In: CHAUL, N. F. (Org.). Goiás: identidade, paisagem e tradição. Goiânia: Ed. da UCG, 2001. p. 75-121.

DELUMEAU, J. História do medo no Ocidente: 1300-1800. São Paulo: Companhia das Letras, 1989. ÉLIS, B. Chegou o governador. Rio de Janeiro: José Olympio, 1998.

FARIA, S. C. A colônia em movimento. Fortuna e familia no cotidiano colonial. Rio de Janeiro: Nova Fronteira, 1998.

FRAGOSO, J. A formação da economia colonial no Rio de Janeiro e de sua primeira elite senhorial (séculos XVI-XVII). FRAGOSO, J.; BICALHO, M. F; GOUVÊA, M. F. (org.). O Antigo Regime nos Trópicos: a dinâmica imperial portuguesa (séculos XVI-XVIII). Rio de Janeiro: Civilização Brasileira, 2001. p. 29-72. 
FRAGOSO, J. Apontamentos para uma metodologia em História Social a partir de assentos paroquiais (Rio de Janeiro, séculos XVII e XVIII). In: FRAGOSO, J.; GUEDES, R.; SAMPAIO, A. C. J. de. (org.). Arquivos paroquiais e História social na América lusa: métodos e técnicas na reinvenção de um corpus documental. Rio de Janeiro: Mauad X/ART, 2014. p. 21-125.

FRAGOSO, J. E as plantations viraram fumaça: nobreza principal da terra, Antigo Regime e escravidão mercantil. História, v. 34, n. 2, p. 58-107, 2015.

FRAGOSO, J. Elite das senzalas e nobreza da terra numa sociedade rural do Antigo Regime nos trópicos: Campo Grande (Rio de Janeiro), 1704-1741. In: FRAGOSO, J.; GOUVÊA, M de F. (org.). O Brasil colonial 1720-1821. v. 3. Rio de Janeiro: Civilização Brasileira, 2016. p.159-240.

FRAGOSO, J. La guerre est finie: notas para a investigação em História Social na América lusa entre os séculos XVI e XVIII. In: FRAGOSO, J.; GOUVÊA, M. de F. (org.). O Brasil colonial (ca.1443 - ca.1530). $3^{\mathrm{a}}$ Ed. Rio de Janeiro: Civilização Brasileira, 2018. p. 7-40.

FRAGOSO, J. Poderes e mercês nas conquistas americanas de Portugal (séculos XVII e XVIII): apontamentos para as relações centro e periferia na monarquia pluricontinental lusa. In: FRAGOSO, J.; MONTEIRO, N. G. (org.). Um reino e suas repúblicas no atlântico: comunicações políticas entre Portugal, Brasil e Angola nos séculos XVII e XVIII. Rio de Janeiro: Civilização Brasileira, 2017. p. 49-100.

FREITAS, L. C. B. F. de. Poder e paixão. A saga dos Caiado. Goiânia: Cânone, 2009.

FREYRE, G. Casa Grande \& Senzala. Formação da família brasileira sob o regime da economia patriarcal. Rio de Janeiro: José Olympio; Brasília: INL, 1983.

GUEDES, R. Livros paroquiais de batismo. escravidão e qualidades de cor (Santíssimo Sacramento da Sé, Rio de Janeiro, séculos XVII-XVIII). In: FRAGOSO, J.; GUEDES, R.; SAMPAIO, A. C. J. de (org). Arquivos paroquiais e história social na América lusa (séculos XVI e XVIII). Rio de Janeiro: Mauad X, 2014. p. 127-186.

HAMEISTER, M. D. Para dar calor à nova povoação: estudo sobre estratégias sociais e familiares a partir dos registros batismais da vila do Rio Grande (1738-1763). Rio de Janeiro: UFRJ, 2006.

HESPANHA, A. M. Imbecilitas. As bem-aventuranças da inferioridade nas sociedades de Antigo Regime. São Paulo: Annablume, 2010.

HESPANHA, A. M. Introdução: os poderes, os modelos e os instrumentos de controle. In: MONTEIRO, N. G. História da vida privada em Portugal. Lisboa: Círculo de Leitores, 2011. p. $12-31$.

MORAES, C. de C. Do corpo místico de Cristo. Goiânia: Ed. da UFG, 2012.

MOREIRA, W. C. Historicidades e representações: celibato, conjugalidades e paternidades sacrílegas em Goiás, 1824-1896. Dissertação (Mestrado em História) - Universidade Federal de Goiás, Goiânia, 2010.

PAIVA, E. F. Escravos e Libertos nas Minas Gerais do Século XVIII: estratégias de resistência através dos testamentos. São Paulo: Annablume, 2009.

PINHEIRO, A. C. C. Família Caldas - documentos interessantes. Inédito. (digitado) 2010.

PINHEIRO, A C. C. Tronco e vergônteas. Descendentes de Luis Manoel da Silva Caldas. Goiânia: Bandeirante, 2002.

POHL, J. E. Viagem ao interior do Brasil. Belo Horizonte: Itatiaia, 1976. 
RIBEIRO J. E. Viagens, viajantes e livros de viagem: Goiás na primeira metade do século XIX (1812-1850). Dissertação (Mestrado em História) - Universidade Estadual Paulista, Franca, 2004.

SAINT-HILAIRE, A. de. Viagem à Província de Goiás. Belo Horizonte: Itatiaia, 1975.

SILVEIRA, A. da S. O amor possivel: um estudo sobre o concubinato no Bispado do Rio de Janeiro em fins do século XVIII e no XIX. Tese (Doutorado em História) - Universidade de Campinas, Unicamp, 2005.

SOARES, M. S. A remissão do cativeiro. A dádiva da alforria e o governo dos escravos nos Campos dos Goitacazes, c. 1750-1830. Rio de Janeiro: Apicuri, 2009.

TELES, J. M. Vida e obra de Silva e Souza. Goiânia: Ed da UFG, 1998.

VIDE, S. M. da. Constituições primeiras do Arcebispado da Babia, 1707. Impressas em Lisboa no anno de 1719. São Paulo: Typographia 2 de Dezembro de Antonio Louzada Antunes, 1853. Edição Senado Federal. 